\title{
Effect of feeding sweet sorghum stover based complete ration on nutrient utilization in Nellore lambs
}

\author{
Jagannatham Babu ${ }^{1}$, Nagireddy Nalini Kumari ${ }^{1}$, Yerradoddi Ramana Reddy², Thirunahari Raghunandan ${ }^{3}$ and
} Kalakuntla Sridhar

1. Department of Animal Nutrition, College of Veterinary Science, S. V. Veterinary University, Hyderabad, Andhra Pradesh, India; 2. Visiting Senior Scientist, International Livestock Research Institute, Patancheru, Hyderabad, Andhra Pradesh, India; 3. Instructional Livestock Farm Complex, College of Veterinary Science, S. V. Veterinary University, Hyderabad, Andhra Pradesh, India.

Corresponding author: Kalakuntla Sridhar, e-mail: sri.vety@gmail.com, JB: jagankalyan@yahoo.co.in, NNK: nalini_reddy123@yahoo.co.in, YRR: ramanayr19@yahoo.co.in, TR: drtrn@rediffmail.com

Received: 11-07-2014, Revised: 11-10-2014, Accepted: 19-10-2014, Published online: 19-11-2014

doi: 10.14202/vetworld.2014.970-975. How to cite this article: Babu J, Nalini Kumari N, Raman Reddy Y, Raghunandan T, Sridhar K (2014) Effect of feeding sweet sorghum stover based complete ration on nutrient utilization in Nellore lambs, Veterinary World 7(11): 970-975.

\begin{abstract}
Aim: The present study was carried out to evaluate the nutrient digestibility of sweet sorghum stover, an unconventional roughage source in ram lambs in comparison to conventional sorghum and maize stovers.

Materials and Methods: 18 Nellore ram lambs aged about 3 months (average body weight $15.65 \pm 0.10 \mathrm{~kg}$ ) were randomly allotted to three complete rations formulated with roughage to concentrate ratio of 60:40 using sorghum stover (D1), maize stover (D2) and sweet sorghum stover (D3) as roughage source for a period of 120 days. At the end of the growth trial, a metabolism trial was conducted to evaluate the nutrient utilization of the complete diets.

Results: There was no significant difference in nutrient digestibility of dry matter, organic matter, crude protein (CP), crude fibre, ether extract and nitrogen free extract in ram lambs fed D1, D2 and D3 diets, respectively. The digestibilities of acid detergent fibre and neutral detergent fibre did not differ significantly among the ram lambs fed various experimental diets. All the lambs were on positive nitrogen balance. Nitrogen balance was comparable among the various groups. The digestible CP and total digestible nutrients, digestible energy and metabolisable energy content of D1, D2 and D3 diets did not show any significant difference.
\end{abstract}

Conclusion: It can be concluded that, sweet sorghum stover can be incorporated in the complete diets of sheep at $60 \%$ level by replacing conventional roughages such as sorghum stover and maize stover, processed as mash form without affecting the voluntary intake and digestibility of nutrients.

Keywords: complete ration, lambs, nutrient utilization, sweet sorghum stover.

\section{Introduction}

Sheep are important elsewhere, particularly in the developing countries of Africa and Asia, which have many adapted indigenous breeds. Each of these continents, in fact, has a greater number of sheep produces more sheep meat annually, in spite of lower production per head. This requires significant contribution by improving per animal productivity, however, the inability of small holder producers to feed animals adequately throughout the year and shrinkage of grazing lands are remained as major constraints to achieve the target [1]. To overcome such problems we need to develop another alternate economise feeding systems.

One of the alternative crop residues is sweet sorghum stover, an untapped roughage source. Sweet sorghum (Sorghum bicolor L. Moench), which is similar to grain sorghum but the stalks are juicy and rich in fermentable sugars as high as $15-18 \%$ with cane yield of $40 \mathrm{t} / \mathrm{ha}$. It is well adapted to the semi-arid tropics.

Copyright: The authors. This article is an open access article licensed under the terms of the Creative Commons Attributin License (http:// creative commons.org/licenses/by/2.0) which permits unrestricted use, distribution and reproduction in any medium, provided the work is properly cited.
The crop only needs 12-15 inches of rain during the season. Therefore, it is suitable for dry land production or limited irrigation. It is one of the most efferent dry land perennial crops in areas that do not have a winter freeze. It is, therefore, the fifth most important cereal crop in the world. The major producers are the United States, India, Nigeria, China, Mexico, Sudan and Argentina. Sudan (8.95 $\mathrm{m} \mathrm{ha}$ ) is the largest sorghum grower in the world followed by India (8.45 m ha) and Nigeria (7.81 $\mathrm{m} \mathrm{ha}$ ) [2]. Sweet sorghum provides grain for human consumption and fodder from stover to livestock [3]. Earlier much work has not been done regarding the usage of sweet sorghum stover as source of roughage in feeding of sheep.

The nutritive value of crop residues is low and when fed as such cannot maintain the livestock. Therefore, incorporation of concentrate in animal diets is needed to overcome nutrients requirements such as protein, mineral and vitamins and optimize the efficiency of feed utilization for growth. The concept of complete feed (mixing of dry roughages and concentrate feed ingredients) becoming more popular in India and this product can be fed as a sole source of balanced nutrients. This system also helps 
in improving utilization of low grade fibrous residues and reduces the refusal of unpalatable portion of feedstuffs, thus reduces the feed waste and improves the nutrient utilization [4].

In this context, we made an attempt to observe the nutrient digestibility in Nellore ram lambs by comparing conventional crop residues (maize and sorghum stover) with sweet sorghum stover as complete feed.

\section{Materials and Methods}

Ethical approval

The experiment was approved by Institutional animal ethics committee.

\section{Site of study}

The experiment was conducted at the Department of Animal Nutrition, College of Veterinary Science, Rajendranagar, Hyderabad, Andhra Pradesh, India. The ambient temperature and relative humidity values during the period of study were in the range of $28-42^{\circ} \mathrm{C}$ and $28-32 \%$, respectively.

\section{Experimental diets and animals rearing}

The three experimental complete diets were prepared by using different roughages i.e., sorghum stover (D1), maize stover (D2) and sweet sorghum stover (D3) at $60 \%$ level as roughage source along with other concentrate ingredients and processed into mash form. Ingredient compositions of the experimental diets were presented in Table-1. 18 ram lambs aged 3 months with a mean body weight of $15.4 \pm 0.2 \mathrm{~kg}$ were divided randomly into three groups of six animals each in a completely randomized design. All the animals were housed in well-ventilated pens $(4 \mathrm{~m} \times$ $3 \mathrm{~m}$ ) and maintained healthy surroundings and proper cleanliness during the experimental period. They were dewormed at the beginning of the experiment and again in the middle of the experiment. The three experimental diets (D1, D2 and D3) were randomly allotted to three groups of ram lambs. The respective diets were offered at $9.00 \mathrm{~h}$ and $15.00 \mathrm{~h}$ daily for 120 days. The animals were offered weighed quantities of respective

Table-1: Ingredient composition of experimental diets.

\begin{tabular}{lccc}
\hline Item & D1 & D2 & D3 \\
\hline Ingredient (\%) & & & \\
Sorghum stover & 60 & - & - \\
Maize stover & - & 60 & - \\
Sweet sorghum stover & - & - & 60 \\
Maize & 12.4 & 12.4 & 12.4 \\
GNC & 6.8 & 6.8 & 6.8 \\
SFC & 8 & 8 & 8 \\
DORB & 9 & 9 & 9 \\
Molasses & 2 & 2 & 2 \\
Urea & 0.6 & 0.6 & 0.6 \\
Mineral mixture & 0.8 & 0.8 & 0.8 \\
Salt & 0.4 & 0.4 & 0.4 \\
\hline
\end{tabular}

D1, D2, D3 refers to complete rations of sorghum stover (D1), maize stover (D2) and sweet sorghum stover (D3) with roughage to concentrate ratio 60:40 respectively. GNC=Ground nut cake; SFC=Sun flower cake; $\mathrm{DORB}=\mathrm{De}$ oiled rice bran complete diets ad libitum. Residues, if any, were weighed on the next day morning before offering of feed. Clean, fresh and wholesome water was made available to each animal at all the time. Experimental animals were shifted to metabolic cages at end of the growth trial.

\section{Metabolism study}

At the end of growth trial, experimental animals were shifted to hygiene, well ventilated metabolic cages and allowed to feed on their respective diets @ $90 \%$ of their required intake. Animals had access to feed and water throughout the experiment. Animals were acclimatized to metabolic cages for 5 days prior to collection period. During the 7-day collection period, the amounts of feed distributed and individual refusals, feces, and urine were weighed daily. During the period of metabolism trial, $24 \mathrm{~h}$ collection of feces was made using fecal bags harnessed to the ram lambs. Urine was collected in glass bottles kept at the bottom of the metabolic cages, which were added with $50 \mathrm{ml}$ of $5 \%$ sulphuric acid daily to avoid nitrogen loss. Representative samples of each feed offered, refusals, and feces were collected for 7 days and composited. After the estimation of dry matter (DM), the samples of the all experimental feed, refusals and feces ground separately in a laboratory Wiley mill through $1 \mathrm{~mm}$ screen and preserved in air tight bottles for subsequent analysis. For balance studies, 5\% total urine voided daily by each animal, after thorough mixing, was composited and preserved in glass bottles and kept in refrigerator till analysed for nitrogen content.

\section{Chemical analysis}

Feed, feces, and urine samples were analyzed for N using "terbotherm" and "vapodest" (Gerhard, Germany) analysed on micro-Kjeldal method [5]. $\mathrm{DM}$, ether extract (EE), and total ash were determined according to procedures described by Association of Official Analytical Chemists [5]. Cell wall constituents in feeds, feces, and residues were performed as per the method described by Van Soest et al. [6]. Ca was estimated as per the method described by Talapatra et al. [7]. P was determined colorimetrically as per the method of Ward and Johnston [8].

\section{Statistical analysis}

The data was subjected to one-way analysis of variance. The differences between the means were tested by significance using Duncan's multiple range test [9]. All the statistical procedures were carried out as per the procedures of Snedecor and Cochran [10] by programming and processing in computer.

\section{Results}

\section{Chemical composition and nutrient digestibility}

Chemical composition of stovers is presented in Table-2. The DM, organic matter (OM), crude fibre (CF), EE, nitrogen free extract (NFE), neutral detergent fibre (NDF) and acid detergent fibre (ADF) contents of sorghum stover, maize stover and sweet 
sorghum stover on DM basis were comparable and which were ranged from 93.00 to $94.60,90.25$ to $90.55,36.80$ to $38.60,45.53$ to $46.68,75.20$ to 76.60 , 41.74 to $43.54 \%$, respectively. Whereas protein content was less $(4.01 \%)$ in sorghum stover compared to other two stovers (Table-2). Similarly, chemical compositions of experimental complete diets were also comparable among the dietary treatments with exception of protein which was lower in sorghum stover based complete diet (Table-3).

The dietary treatments had no significant $(\mathrm{p}>0.05)$ difference in the digestibility (\%) of DM, OM, crude protein (CP), EE, CF, NDF and ADF which were ranged from 60.05 to $61.55,61.01$ to $64.08,61.73$ to $64.93,69.81$ to $73.17,57.30$ to $59.48,66.28$ to 69.72 , 52.26 to 54.80 , 46.31 to 48.43 , respectively (Table-4).

\section{Nitrogen balance}

Nitrogen balance in experimental ram lambs was $5.81 \pm 0.21,6.23 \pm 0.56$ and $6.91 \pm 0.87 \mathrm{~g} /$ day for D1, D2 and D3 diets, respectively. Incorporation of unconventional feed source (sweet sorghum stover) as complete diet in lambs feed did not affect $(\mathrm{p}>0.05)$

Table-2: Chemical composition (\% DMB)* of experimental stovers.

\begin{tabular}{lccc}
\hline I tem & $\begin{array}{c}\text { Sorghum } \\
\text { stover }\end{array}$ & $\begin{array}{c}\text { Maize } \\
\text { stover }\end{array}$ & $\begin{array}{c}\text { Sweet sorghum } \\
\text { stover }\end{array}$ \\
\hline DM & 93.00 & 93.80 & 94.60 \\
OM & 90.55 & 90.26 & 90.25 \\
CP & 4.01 & 5.52 & 5.53 \\
EE & 1.26 & 1.31 & 1.28 \\
CF & 38.60 & 37.90 & 36.80 \\
NFE & 46.68 & 45.53 & 46.64 \\
NDF & 76.60 & 75.20 & 76.48 \\
ADF & 43.54 & 42.54 & 41.74 \\
\hline
\end{tabular}

Each value is an average of triplicate analysis, * On dry matter basis except for dry matter. $\mathrm{DMB}=$ Dry matter basis, $\mathrm{DM}=$ Dry matter, $\mathrm{EE}=$ Ether extract, $\mathrm{CF}=$ Crude fibre, NFE $=$ Nitrogen free extract, $N D F=$ Neutral detergent fibre, $A D F=$ Acid detergent fibre, $O M=$ Organic matter, $\mathrm{CP}=$ Crude protein

Table-3: Chemical composition (\% DMB)* of experimental complete diets.

\begin{tabular}{lccc}
\hline Item & D1 & D2 & D3 \\
\hline DM & 91.25 & 91.65 & 92.05 \\
OM & 90.35 & 90.20 & 90.20 \\
CP & 10.45 & 11.31 & 11.38 \\
EE & 1.34 & 1.52 & 1.46 \\
CF & 29.22 & 27.85 & 27.42 \\
NFE & 49.30 & 48.90 & 49.94 \\
NDF & 56.56 & 55.72 & 56.48 \\
ADF & 32.15 & 30.98 & 31.87 \\
\hline
\end{tabular}

D1, D2, D3 refers to complete rations of sorghum stover (D1), maize stover (D2) and sweet sorghum stover (D3) with roughage to concentrate ratio 60:40 respectively; Each value is an average of triplicate analysis; * On dry matter basis except for dry matter. $\mathrm{DM}=$ Dry matter, $\mathrm{DMB}=$ Dry matter basis, $\mathrm{OM}=$ Organic matter, $\mathrm{EE}=\mathrm{Ether}$ extract, $\mathrm{CF}=$ Crude fibre, $\mathrm{NFE}=$ Nitrogen free extract, $N D F=$ Neutral detergent fibre, $A D F=A c i d$ detergent fibre, $\mathrm{CP}=$ Crude protein the average $\mathrm{N}$ intake (g/day), average daily nitrogen balance (g/day), $\mathrm{N}$ balance (percentage of intake) and $\mathrm{N}$ balance (percentage of absorbed) (Table-5).

\section{Nutritive value}

The DM intake (DMI) $/ \mathrm{kg} \mathrm{w}^{0.75}$ was $96.53 \pm 6.94$, $98.62 \pm 5.78$ and $103.12 \pm 8.36$ g/day, respectively for D1, D2 and D3 diets and the values were not differed significantly $(\mathrm{p}>0.05)$. Similarly, the digestible crude protein (DCP), total digestible nutrients (TDN), digestible energy (DE) and metabolizable energy (ME) values of experimental diets were not affected significantly $(\mathrm{p}>0.05)$ by type of stover present in the complete diets (Table-4).

The DCP (g/day) intake of D3 fed lambs was significantly $(p<0.05)$ higher than those fed D1 and D2 diet. The TDN intake (g/day) was significantly $(\mathrm{p}<0.05)$ higher in lambs fed D3 diet. The daily intakes of DE and ME either per animal or per unit metabolic body size did not differ among the lambs on various diets. The lambs consumed more DM in all groups than requirements stipulated by Indian Council of Agricultural Research (ICAR) (1998) shown in Table-4. The average daily DCP, TDN and ME intakes of lambs fed experimental diets met the DCP (73 g), TDN (510 g) and ME (7.5 MJ/d) requirements at 25 kg body weight, @ 100 g of average daily gain [11].

\section{Discussion}

\section{Chemical composition of experimental diets}

Proximate principles and cell wall constituents were comparable among all of the experimental diets, except CP which was lower in sorghum stover based complete diet as sorghum stover contained $4.01 \%$ CP (Table-1). The non-significant difference in chemical composition was obvious as diets had similar ingredient composition. It was in agreement with Sudheer [12], who observed similar chemical composition among sorghum stover, maize stover and sweet sorghum bagasse based complete diets. The chemical composition of sorghum stover based complete diet was in agreement with the chemical composition reported by Rajmane and Deshmukh [13] and Dhore and Khune [14] who prepared $60 \%$ sorghum stover based complete diets. The chemical composition of sorghum stover based complete mash diet obtained in the present study was also in agreement with the findings of Singh et al. [15]. The chemical composition of maize stover based complete diet was in agreement with the chemical composition reported by Sudheer [12]. The chemical composition of sweet sorghum stover based complete diet was similar to the chemical composition reported with other crop residues (60\%) based complete diets like wheat straw $[16,17]$ wheat straw and spent straw [18], sweet sorghum bagasse [19], bajra straw $[15,20]$, maize stover [15] and sorghum stover $[13,14]$. 
Table-4: Effect of feeding different stover based complete diets on dry matter intake; nutrient digestibility, nutritive value and plane of nutrition in Nellore ram lambs.

\begin{tabular}{|c|c|c|c|c|}
\hline \multirow[t]{2}{*}{ Parameter } & \multicolumn{3}{|c|}{ Rations } & \multirow[t]{2}{*}{ SEM } \\
\hline & D1 & D2 & D3 & \\
\hline Body wt. (kg) & $24.63 \pm 2.33$ & $23.80 \pm 3.6$ & $24.13 \pm 1.41$ & 0.18 \\
\hline DMI g/kg w $w^{0.75}$ & $96.53 \pm 6.94$ & $98.62 \pm 5.78$ & $103.12 \pm 8.36$ & 1.18 \\
\hline DM & $60.05 \pm 1.97$ & $60.23 \pm 1.32$ & $61.55 \pm 2.15$ & 0.31 \\
\hline OM & $61.01 \pm 1.60$ & $63.56 \pm 2.66$ & $64.08 \pm 2.13$ & 0.53 \\
\hline $\mathrm{CP}$ & $61.73 \pm 1.58$ & $63.47 \pm 1.62$ & $64.93 \pm 2.18$ & 0.54 \\
\hline $\mathrm{EE}$ & $69.81 \pm 1.90$ & $72.59 \pm 1.5$ & $73.17 \pm 2.40$ & 0.73 \\
\hline $\mathrm{CF}$ & $58.72 \pm 2.27$ & $57.30 \pm 1.95$ & $59.48 \pm 1.65$ & 0.42 \\
\hline NFE & $66.28 \pm 1.28$ & $67.57 \pm 1.45$ & $69.72 \pm 1.25$ & 0.63 \\
\hline NDF & $52.26 \pm 2.42$ & $53.41 \pm 1.86$ & $54.80 \pm 1.54$ & 0.57 \\
\hline ADF & $46.31 \pm 2.32$ & $47.96 \pm 2.25$ & $48.43 \pm 1.84$ & 0.52 \\
\hline \multicolumn{5}{|l|}{ Nutritive value } \\
\hline DCP (\%) & $6.45 \pm 0.75$ & $7.18 \pm 0.61$ & $7.39 \pm 0.87$ & 0.16 \\
\hline TDN (\%) & $58.41 \pm 1.20$ & $58.66 \pm 1.10$ & $60.92 \pm 1.45$ & 0.51 \\
\hline $\mathrm{DE}(\mathrm{MJ} / \mathrm{kg} \mathrm{DM})$ & $10.78 \pm 1.15$ & $10.82 \pm 1.23$ & $11.24 \pm 1.86$ & 0.83 \\
\hline $\mathrm{ME}(\mathrm{MJ} / \mathrm{kg} \mathrm{DM})$ & $8.84 \pm 0.63$ & $8.88 \pm 0.54$ & $9.22 \pm 0.67$ & 0.08 \\
\hline \multicolumn{5}{|l|}{ Plane of nutrition } \\
\hline DCP (g/day) & $68.82^{c} \pm 3.86$ & $76.33^{b} \pm 2.59$ & $82.99^{\mathrm{a}} \pm 1.72$ & 2.32 \\
\hline TDN (g/day) & $623.23^{b} \pm 2.68$ & $623.56^{b} \pm 3.52$ & $684.13^{\mathrm{a}} \pm 3.09$ & 12.13 \\
\hline $\mathrm{DE}\left(\mathrm{MJ} / \mathrm{kg} \mathrm{w}^{0.75}\right)$ & $1.04 \pm 0.15$ & $1.07 \pm 0.12$ & $1.16 \pm 0.17$ & 0.19 \\
\hline $\mathrm{ME}\left(\mathrm{MJ} / \mathrm{kg} \mathrm{w}^{0.75}\right)$ & $0.85 \pm 0.08$ & $0.88 \pm 0.10$ & $0.95 \pm 0.09$ & 0.02 \\
\hline
\end{tabular}

a,b,c value bearing different superscripts in a row differ significantly $(P<0.05), D 1, D 2, D 3$ refers to complete rations of sorghum stover (D1), maize stover (D2) and sweet sorghum stover (D3) with roughage to concentrate ratio 60:40 respectively. $\mathrm{SEM}=$ Standard error of the mean, $\mathrm{DMI}=$ Dry matter intake, $\mathrm{DCP}=$ Digestible crude protein, TDN=Total digestible nutrients, $\mathrm{DE}=$ Digestible energy, $\mathrm{ME}=$ Metabolizable energy, $\mathrm{DM}=$ Dry matter, $\mathrm{OM}=$ Organic matter, $\mathrm{EE}=\mathrm{Ether}$ extract, $\mathrm{CF}=$ Crude fibre, $\mathrm{NFE}=$ Nitrogen free extract, $\mathrm{NDF}=$ Neutral detergent fibre, $\mathrm{ADF}=\mathrm{Acid}$ detergent fibre, $\mathrm{CP}=\mathrm{Crude}$ protein

Table-5: Effect of feeding different stover based complete diets on nitrogen balance in Nellore ram lambs.

\begin{tabular}{lcccc}
\hline Parameter & \multicolumn{3}{c}{ Complete diet } & SEM \\
\cline { 2 - 4 } & D1 & D2 & $20.44 \pm 0.12$ & 0.43 \\
\hline N intake (g/day) & $17.83 \pm 0.31$ & $19.24 \pm 0.45$ & $10.60 \pm 0.98$ & 0.21 \\
Faecal N loss (g/day) & $9.31 \pm 1.08$ & $10.23 \pm 1.56$ & $2.93 \pm 0.89$ & 0.04 \\
Urinary N loss (g/day) & $2.71 \pm 0.96$ & $2.78 \pm 0.87$ & $13.56 \pm 0.56$ & 0.32 \\
Total N loss (g/day) & $12.02 \pm 0.11$ & $13.01 \pm 0.11$ & $9.84 \pm 1.98$ & 0.23 \\
N absorbed (g/day) & $8.52 \pm 1.54$ & $9.01 \pm 2.07$ & $6.91 \pm 0.87$ & 0.18 \\
N balance (g/day) & $5.81 \pm 0.21$ & $6.23 \pm 0.56$ & $33.81 \pm 1.20$ & 0.31 \\
N balance (\% of intake) & $32.59 \pm 1.32$ & $32.38 \pm 1.30$ & $70.22 \pm 1.87$ & 0.36 \\
N balance (\% of absorbed) & $68.23 \pm 2.58$ & $69.15 \pm 2.21$ &
\end{tabular}

D1, D2, D3 refers to complete rations of sorghum stover (D1), maize stover (D2) and sweet sorghum stover (D3) with roughage to concentrate ratio 60:40 respectively. SEM=Standard error of the mean

\section{Voluntary feed intake}

The DMI was similar among the experimental diets (Table-4). Similar DMI (1134 g/day) was reported by Nalini Kumari et al. [19] with 60\% sweet sorghum bagasse based complete diet in lambs. Blummel et al. [21] reported no statistical differences in DMIs between bulls fed the sweet sorghum bagasse plus stripped leaf based blocks and those fed sorghum stover based commercial feed block. Dhuria et al. [20] reported $81.8 \mathrm{~g}$ of DMI $/ \mathrm{kg} \mathrm{w}^{0.75}$ in sheep fed bajra straw (60\% level) based complete feed. The similar DMI observed with the experimental ration containing D3 in the present study indicated that the sweet sorghum stover was equally palatable in comparison with the rations containing sorghum stover and maize stover. The results obtained were in agreement with Seshaiah and Ramana Reddy [22], who found that the DMI/kg metabolic body weight was similar in lactating graded Murrah buffaloes fed sweet sorghum bagasse mash diet with sorghum stover mash diet. Similar results were found by Jadhav and Deshmukh [23] on two complete rations containing $60 \%$ level of black gram straw and wheat straw in sheep.

\section{Nutrient digestibility}

No significant difference was found among the three rations in the digestibility coefficient of DM, OM, CP, EE, CF, NFE, NDF and ADF. Our results were in consistent with the findings of Seshaiah and Ramana Reddy [22] who observed no difference (p>0.05) in the digestibility coefficient of DM, OM, CP, EE, CF, NFE, NDF and ADF in graded Murrah calves by replacing the conventional roughage source (sorghum stover) with unconventional roughage source (sweet sorghum stover bagasse) which were 
supplemented as complete mash diets (50:50 roughage to concentrate ratio). Whereas, Reddy and Reddy [24] stated that the grinding and blending of crop residues with concentrate (in a given ratio) into mash was found to be useful for efficient utilisation of crop residues in ruminants. In the present study, digestibility coefficient of proximate principles and fibre fractions were in consistent with the findings of Nalini Kumari et al. [19] who did experiment on ram lambs which were fed on sweet sorghum bagasse based complete diets containing 60:40 roughage to concentrate ratio. Our results were also similar with findings of Dhuria et al. [20] and Dhore and Khune [14] who used 60\% sorghum stover based complete diet in male kids and $60 \%$ wheat straw, gram straw and bajra straw based complete diets in sheep.

\section{Nitrogen balance}

Positive nitrogen $(\mathrm{N})$ balance was recorded in all the experimental lambs indicating that all experimental diets met the $\mathrm{N}$ requirement of the experimental ram lambs. The $\mathrm{N}$ balance was non-significantly (p>0.05) 19 and 11\% higher in lambs fed D3 than those fed D1 and D2 diets. Positive $\mathrm{N}$ balance was also reported in lambs fed bajra straw based complete mash diet [20,25] and gram straw based diet [26]. Seshaiah and Ramana Reddy [22] reported higher N balance in graded Murrah buffalo calves fed sweet sorghum bagasse based complete mash diet than those fed sorghum stover based complete mash diet. The results of the present study showed that, the incorporation of sweet sorghum stover at $60 \%$ level had no adverse effect on $\mathrm{N}$ absorption and utilization.

\section{Nutritive value and plane of nutrition}

No significant difference was observed in DCP (\%) and TDN (\%) contents among the ram lambs fed on various roughage based complete diets (Table-4). The $15 \%$ higher DCP content of D3 diet when compared to D1 diet may be attributed to its higher CP content and apparently higher digestibility. No significant difference was found in ME and DE values (MJ/kg DM) of the experimental diets D1, D2 and D3. The observed DCP and TDN values of the present study were higher than the values reported by Yadav and Deshmukh [18] and Jadhav and Deshmukh [23] in lambs fed wheat straw (60\%) based complete diets. The results suggested that the inclusion of $60 \%$ sweet sorghum stover had a better effect on nutrient utilization.

The DCP intake was significantly higher by 9 and $21 \%$ in D3 diet when compared to D2 and D1 diets. The higher DCP intake in lambs fed D3 diet may be attributed to its higher CP and DCP contents and apparently higher DMI. These findings were in agreement with Jadhav and Deshmukh [23] in lambs fed wheat straw and black gram straw based complete diets. The TDN intake was also significantly higher in D3 diet compared to D1 and D2 diets. The higher TDN of D3 diet may be attributed to its non-significantly higher nutrient digestibilities and DMI. Nalini
Kumari et al. [19] reported 60.26 and 552.79 g intake of DCP and TDN respectively in ram lambs fed sweet sorghum bagasse based complete mash diet. ME and DE intakes (MJ/day) of ram lambs fed experimental diets D1, D2 and D3 were $8.84 \pm 0.63$ and $10.78 \pm 1.15$, $8.88 \pm 0.54$ and $10.82 \pm 1.23$ and $9.22 \pm 0.67$ and 11.24 \pm 1.86 , respectively. Nalini Kumari et al. [19] reported ME (MJ/day) and DE (MJ/day) of 9.12 and 11.04 in lambs fed sweet sorghum bagasse based complete mash diet (60:40 roughage to concentrate ratio). The nutrient intake of lambs was comparable to the reports of, Yadav and Deshmukh [18] and Thirumalesh et al. [27]. The plane of nutrition (Table-4) of the ram lambs fed experimental diets containing different roughage sources in the present study indicated that the observed DCP and TDN intakes were met the nutrient requirements suggested by ICAR (1998) for the lambs of $25 \mathrm{~kg}$ body weight and at the rate of $100 \mathrm{~g} /$ day. The plane of nutrition in the three groups fed sorghum, maize and sweet sorghum stovers based complete diets at $60 \%$ level was satisfactory as indicated by the gain in body weight (Table-5).

\section{Conclusion}

The results from the present study indicated that sweet sorghum stover which is a newer and cheaper untapped roughage source could be utilized at $60 \%$ level (replacing sorghum stover and maize stover) in complete diet processed into mash form without affecting the voluntary feed intake and nutrient digestibility in ram lambs.

\section{Authors' Contributions}

JB, NNR, YRR, and TR implemented the study design. JB, NNR and KS recorded the data and analysed. NNR and KS drafted the manuscript. JB, NNR, YRR, TR and KS revised the manuscript. All authors read and approved the final manuscript.

\section{Acknowledgments}

The authors are thankful to the authorities of National Agricultural Innovation Project (NAIP), ICAR, New Delhi, India for providing financial assistance to carry out this investigation. Appreciation is expressed to staff members of the College of Veterinary Science, Hyderabad for their cooperation and support for smooth conduct of this study.

\section{Competing I nterests}

The authors declare that they have no competing interests.

\section{References}

1. Anbarasu, C., Dutta, N., Sharma, K. and Rawat, M. (2004) Response of goats to partial replacement of dietary protein by a leaf meal mixture containing Leucaena leucocephala, Morus alba and Tectona grandis. Small Ruminant. Res., 51: 47-56.

2. FAO. (2010) Food and Agricultural Organization, Rome, Italy.

3. Shukla, G.K., Gupta, S.K., Singh, L., Rao, S.S., 
Rathavathi, C.V. and Dayakar Rao, B. (2006) Successful pilot production of bio-ethanol from sweet sorghum in sub-tropical India. Jowar Samachar., 2: 1.

4. Reddy, G.V.N. and Reddy, J.L. (2003) Effect of cotton stalks based complete diet on growth and carcass characteristics in sheep and goats in field condition. Indian J. Anim. Nutr., 20(1): 97-100.

5. AOAC. (1997) Association of Official Analytical Chemists. $16^{\text {th }}$ ed. Official Methods of Analysis, Washington, DC.

6. Van Soest, P.V., Robertson, J.B., and Lewis, B.A. (1991) Methods for dietary fiber, neutral detergent fiber, and nonstarch polysaccharides in relation to animal nutrition. $J$. Dairy Sci., 74(10): 3583-3597.

7. Talapatra, S.K., Ray, S.C. and Sen, K.C. (1940) The analysis of mineral constituents in biological materials. 1. Estimation of phosphorus, chlorine, calcium, magnesium, sodium and potassium in food-stuffs. Indian J. Vet. Sci. Anim. Husbandry, 10: 243-258.

8. Ward, G.M. and Johnston, F.B. (1962) Chemical methods of plants analysis. Publ. 1064. Research Branch, Department of Agriculture, Canada.

9. Duncan, D.B. (1955) Multiple range and multiple F tests. Biometrics, 11(1): 1-42.

10. Snedecor, G.W., Cochran, W.G. (1994) Statistical Methods. $8^{\text {th }}$ ed. Iowa State University Press, Ames, Iowa, USA.

11. ICAR. (1998) Nutrient requirements of livestock and poultry. Indian Council of Agricultural Research, Pusa, New Delhi.

12. Sudheer, A.B. (2010) Evaluation of processed complete rations containing various roughages in male sheep. MVSc. Thesis Submitted to College of Veterinary Science, SV Veterinary University.

13. Rajmane, S.M. and Deshmukh, S.V. (2000) Nutritional evaluation of complete rations in goats. Indian J. Anim. Nutr., 17(3): 246-248.

14. Dhore, R.N. and Khune, R.K. (2006) Nutrient intake and growth performance of kids fed sorghum stover based pelleted complete feed. Indian J. Small Ruminants, 12(2): 156-161.

15. Singh, J., Sharma, A., Handa, M.C. and Nagra, S.S. (2009) Effect of different concentrate roughage ratio on growth performance, carcass characterstics and economics of production of beetal kids under stall feeding. Indian J. Anim. Nutr., 26(4): 354-357.

16. Flachowsky, G., Koch, H., Tiroke, K. and Matthey, M. (1993) Influence of the ratio between wheat straw and ground barley, ground corn or dried sugar beet pulp on in sacco dry matter degradation of ryegrass and wheat straw, rumen fermentation and apparent digestibility in sheep.
Arch. Anim. Nutr., 43(2): 157-167.

17. Chatterjee, P.N., Kamra, D.N. and Agarwal, N. (2006) Effect of roughage source, protein and energy levels on in vitro fermentation and methanogenesis. Indian J. Anim. Nutr., 23(2): 72-77.

18. Yadav, S.G. and Deshmukh, S.V. (2001) Nutritional evaluation of spent straw in complete ration of sheep. Indian $J$. Anim. Nutr., 18(2): 151-155.

19. Nalini Kumari, N., Reddy, Y.R., Blummel, M., Nagalakshmi, D., Sudhakar, K., Reddy, V.R. and Reddy, C.R. (2012) Effect of roughage to concentrate ratio of sweet sorghum (Sorghum biclor L. Moench) bagasse-based complete diet on nutrient utilization and microbial $\mathrm{N}$ supply in lambs. Trop. Anim. Health Prod., 44(7): 1717-1724.

20. Dhuria, R.K., Purohit, G.R. and Sharma, T. (2007) Evaluation of bajra straw based complete feed in sheep. Indian J. Anim. Nutr., 24(4): 209-211.

21. Blummel, M., Rao, S.S., Palaniswami, S., Shah, L. and Reddy, B.V. (2009) Evaluation of sweet sorghum (Sorghum bicolor L. Moench) used for bio-ethonol production in the context of optimizing whole plant utilization. Anim. Nutr. Feed Technol., 9(1): 1-10.

22. Seshaiah, C.H.V. and Ramana Reddy, Y. (2012) Effect of feeding processed sweet sorghum (sorghum bicolour (l) moench) bagasse based total mixed ration on performance of graded murrah buffaloes. J. Anim. Prod. Adv., 2(7): 329-334.

23. Jadhav, S.E. and Deshmukh, S.V. (2001) Evaluation of complete rations containing black gram straw and wheat straw in sheep. Indian J. Anim. Nutr., 18(2): 190-193.

24. Reddy, R.Y. and Reddy, G.V.N. (2011) Processed crop residue based complete diets for enhancing ruminant performance. In: FAO Animal Production and Health Proceedings. FAO, Rome.

25. Madhavi, K., Reddy, T.J., Reddy, Y.R. and Reddy, G.V.N. (2009) Effect of feeding differently processed neem seed cake (Azadirachta indica) based complete diet on intake and nutrient utilization in Nellore sheep. Indian J. Anim. Nutr., 26(2): 130-134.

26. Dhuria, R.K., Purohit, G.R. and Sharma, T. (2004) Nutritional evaluation of complete feed containing gram (Cicer arietinum) straw in sheep. Indian J. Anim. Nutr., 21(2): 100-103.

27. Thirumalesh, T., Surekha, K. and Reddy, V.N. (2003) Effect of bajra straw based complete diet on nutrient digestibility and rumen metabolism in sheep. Indian J. Anim. Nutr., 20(4): 389-394. 